\title{
The structure of laccase protein and its synthesis by the commercial mushroom Agaricus bisporus
}

\author{
Caroline R. Perry, ${ }^{1} \uparrow$ Stephen E. Matcham, ${ }^{2}$ David A. Wood ${ }^{2}$ \\ and CHRISTOPHER F. THURSTON ${ }^{1 *}$ \\ ${ }^{1}$ Microbial Physiology Research Group, Division of Life Sciences, King's College London, Campden Hill Road, \\ London W8 $7 A H, U K$ \\ ${ }^{2}$ Microbiology and Crop Protection Department, Horticulture Research International, Worthing Road, Littlehampton, \\ West Sussex BN17 6NU, UK
}

(Recieved 6 May 1992; accepted 28 September 1992)

\begin{abstract}
Agaricus bisporus secretes abundant laccase activity into the medium during mycelial growth. SDS-PAGE analysis of extracellular laccase protein, purified from compost extract, showed a predominant band of $65 \mathrm{kDa}$ molecular mass, together with lesser amounts of smaller polypeptides. The main polypeptide was purified electrophoretically. Amino acid sequence analysis of the $\mathrm{N}$-terminal region of the main polypeptide was used to specify the sequence of a 15-residue chemically synthesized peptide ( $\mathrm{N}$-terminal peptide). Rabbit antibodies were raised against pure laccase, electrophoretically purified main polypeptide and the synthetic $\mathrm{N}$-terminal peptide. Electrophoretically purified main polypeptide antibody was further purified by affinity chromatography on laccaseCNBr-Sepharose. Western blot analysis showed that the antigenic behaviour of laccase in compost extract, culture filtrate from malt-extract culture, and the purified enzyme from both sources, differed. The patterns of bands revealed are most simply explained by generation of (proteolytically) partially cleaved enzyme molecules in the culture medium, possibly combined with differences in extent of glycosylation. ${ }^{35}$ S]Methionine incorporation and immunoprecipitation were used to follow laccase synthesis in cultures grown on malt extract. After short-term labelling, a single polypeptide of $68 \mathrm{kDa}$ apparent molecular mass was immunoprecipitated from both mycelial extracts and the culture medium. When poly(A)-containing RNA from malt-extract-grown mycelium was translated in vitro in rabbit reticulocyte lysate, a single polypeptide of about $57 \mathrm{kDa}$ molecular mass was immunoprecipitated, consistent with the previously measured carbohydrate content of $15 \%$ for the pure enzyme. After treatment with $N$-glycanase, the polypeptide showed an increase in mobility during SDS-PAGE consistent with a reduction in molecular mass of about $5 \mathrm{kDa}$, indicating about equal amounts of $N$ - and $O$-linked carbohydrate. $C$-terminal labelling of pure laccase was attempted by transpeptidation with carboxypeptidase $Y$. Although some minor bands were labelled, the main polypeptide was not, indicating that the C-terminus of the enzyme may be blocked.
\end{abstract}

\section{Introduction}

The commercial mushroom Agaricus bisporus is one of several fungi that secrete extracellular laccase(s) for which a function has yet to be clearly established (Reinhammar, 1984). Laccase (polyphenol oxidase: EC 1.10 .3 .2 ) is of interest in A. bisporus for several reasons. First, it is produced abundantly, constituting $2 \%$ of mycelial protein (Wood, 1980a). Secondly, it is dev-

\footnotetext{
* Author for correspondence. Tel. 071333 4276; fax 0713334500.

$\dagger$ Present address: SmithKline Beecham Pharmaceuticals, Brockham Park, Betchworth, Surrey RH3 7AJ, UK.
}

elopmentally regulated, rapid loss of extracellular laccase activity occurring during the enlargement stage of fruit (mushroom) formation (Wood, 1980 b; Smith et al., 1989). Thirdly, the most plausible proposal for laccase function as an extracellular enzyme of white-rot fungi and litter fungi such as $A$. bisporus is a role in ligninolytic growth, that may or may not include a direct contribution to lignin degradation (Ander \& Ericksson. 1976).

Some properties of $A$. bisporus laccase were established from pure enzyme samples obtained on a small scale from malt-extract culture fluid (Wood, 1980a). The enzyme was shown to be a copper-containing glycoprotein with a broad substrate specificity, typical of a 
fungal laccase-type polyphenol oxidase (Wood, 1980a). Whilst this material behaved as a homogeneous pure protein during analytical ultracentrifugation and gel filtration (Wood, 1980a), when subjected to SDS-PAGE, the enzyme was shown to be composed of several polypeptides. Further, when laccase was purified from cultures grown on compost (the commercial substrate), the pattern of polypeptides revealed by SDS-PAGE (Wood, 1980b) was not identical to that previously found for enzyme from malt-extract culture.

Although some progress has been made in experimental analysis of laccase properties under the growth conditions (compost culture) used for commercial production of mushrooms, some experiments such as in vivo labelling and $\mathrm{mRNA}$ isolation at present require laboratory liquid cultures. It is therefore necessary to show that laccase synthesis in compost and malt-extract culture can usefully be compared.

The purpose of this paper is to clarify the structure of A. bisporus laccase and to describe some features of its synthesis.

\section{Methods}

Organism. Agaricus bisporus strain D649 was maintained on malt agar at $25^{\circ} \mathrm{C}$ and subcultured at monthly intervals. Compost cultures were inoculated with D649 commercial spawn [Darmycel (UK), Littlehampton].

Growth in malt extract liquid medium. Static cultures in $3 \%(\mathrm{v} / \mathrm{v})$ malt extract (Boots, Nottingham, UK) medium were inoculated with mycelial fragments generated by shaking mycelium with sterile $4 \mathrm{~mm}$ glass beads and incubated at $25^{\circ} \mathrm{C}$. Mycelium was harvested by filtration. Culture fluid, after filtration, was concentrated tenfold in Minicon disposable concentrator blocks (Amicon) and stored at $-20^{\circ} \mathrm{C}$.

Compost culture. Mushroom compost prepared by the method of Randle (1974), and colonized with A. bisporus D649 from commercial spawn, was extracted prior to fruiting as laccase activity approached its maximum (Wood \& Goodenough, 1977). The extraction was performed by steeping the compost for $20 \mathrm{~min}$ in chilled deionized water using 2 litres per $\mathrm{kg}$ (fresh wt) of compost. The liquor was decanted, strained through Tygan nylon mesh and clarified by passage through a continuous centrifuge exerting $15000 \mathrm{~g}$ (Sharples 1A; Pennwalt, Camberley, UK).

Laccase purification. Laccase was purified from both compost extract and malt-extract culture fluid as described by Matcham \& Wood (1992). The specific activity and electrophoretic properties of the enzyme were comparable to those described previously for the material obtained from small-scale purification (Wood, 1980a).

In vivo labelling. Ten malt extract cultures (total vol. $500 \mathrm{ml}$ ) were centrifuged and the mycelium resuspended in $50 \mathrm{ml}$ of the original medium. Samples of culture fluid and mycelium were taken at 3,6,9 and $24 \mathrm{~h}$ after addition of $\left.1 \cdot 1 \mathrm{mCi}(40 \cdot 3 \mathrm{MBq}){ }^{35} \mathrm{~S}\right]$ methionine $(800 \mathrm{Ci}$ $\mathrm{mmol}^{-1}, 29 \cdot 3 \mathrm{TBq} \mathrm{mmol}^{-1}$; Amersham) to the medium of 11-d-old cultures,

Preparation of mycelial extracts. Mycelial samples were frozen $\left(-70^{\circ} \mathrm{C}\right)$ and blended to a fine powder by $2-3$ min treatment in a domestic electric coffee bean grinder (Braun, Frankfurt, FRG) in the presence of about 2 vols solid $\mathrm{CO}_{2}$ pellets. The mycelial powder and residual solid $\mathrm{CO}_{2}$ were transferred to glass tubes. As the residual $\mathrm{CO}_{2}$ sublimed and before the mycelial fragments had melted, buffer was carefully added: phosphate-buffered saline (PBS), containing $5 \mathrm{~mm}$ dithiothreitol, 1 mm-EDTA and 1 mm-benzamidine for protein analyses; the composition of the buffer mixture for RNA extraction differed (see below). For protein analyses, supernatant extracts were obtained by centrifugation $\left(15000 \mathrm{~g}, 10 \mathrm{~min}, 4^{\circ} \mathrm{C}\right)$ and concentrated 10-fold (Amicon Minicon blocks).

Isolation of poly $(A)$-containing $R N A$. Extraction of RNA using triisopropyl naphthalene sulphonate and phenol/cresol followed by oligo(dT)-cellulose chromatography was performed as described previously for Chlorella fusca (Leonard et al., 1981). DNA was removed from total RNA samples by extraction with 3 M-sodium acetate, 5 mM-EDTA, pH 7. RNA was adsorbed to oligo(dT)-cellulose and eluted twice. From electrophoretic analysis (not shown) there was 10-20\% residual ribosomal RNA in poly(A)-containing RNA samples.

In vitro translation assays. Rabbit reticulocyte lysate assays were performed according to the manufacturer's instructions (Amersham). Each assay $(50 \mu \mathrm{l})$ contained $44 \mu \mathrm{l}$ lysate mixture, $30 \mu \mathrm{Ci}(1 \cdot 1 \mathrm{MBq})$ $\left.{ }^{35} \mathrm{~S}\right]$ methionine (specific activity as above) and up to $2 \mu \mathrm{g}$ poly(A)containing RNA. Samples $(5 \mu \mathrm{l})$ were mixed with loading buffer (see below) for analysis of incorporation into total protein. For immunoprecipitation, $45 \mu \mathrm{l}$ samples were diluted to $100 \mu \mathrm{l}$ with PBS.

Electrophoretic analysis. SDS-PAGE was performed as described by Laemmli (1970) except that samples were heated on a boiling water bath for $5 \mathrm{~min}$ to effect complete denaturation. Gels were stained with Coomassie brilliant blue and dried onto Whatman $3 \mathrm{MM}$ paper for autoradiography using Fuji RX film. Protein concentration for this and other procedures was measured by Lowry's method or by the method of Bradford (1976).

Amino acid sequence analysis. Polypeptides eluted from SDS-gels, or electroblotted directly to polybrene-coated glass-fibre filters, were analysed either at the University of Leeds, UK (SERC facility, Dr Darryl Pappin) or at the AFRC Institute of Animal Physiology and Genetics Research, Babraham, Cambridge, UK (Dr Pat Barker). The sequence of the $\mathrm{N}$-terminus of laccase purified from compost extract was found to be DTKTFNFDLVNTRLA.

Preparation of antibodies. Antibodies were raised in rabbits using three different immunogen preparations. 1. Pure active laccase from compost extract was used without modification. 2. The main polypeptide, electrophoretically purified from pure laccase (ex compost extract) was injected in the presence of $0.5 \%$ SDS. These two immunogens were injected with adjuvant following the procedure described previously (Wood, 1980 a) except that injections were intramuscular. 3. A chemically synthesized peptide identical to the 15 $\mathrm{N}$-terminal amino acid residues of laccase main polypeptide was linked to PPD (purified protein derivative of tuberculin) via an additional cysteine residue, for injection as a haptenized immunogen. Synthesis of the peptide, and the production of the antibody to it, were purchased services from Dr N. Huskisson, AFRC Institute of Animal Physiology and Genetics Research (address above).

Antibodies raised against laccase main polypeptide (2, above) were purified by affinity chromatography for some analyses (stated in figure legends). The fraction of serum protein precipitated by $40 \%$ saturated ammonium sulphate was adsorbed to laccase main polypeptide that had been immobilized by conjugation to $\mathrm{CNBr}$-Sepharose, following the manufacturer's instructions (Pharmacia). After packing the Sepharose suspension into a column and washing with distilled water. the adsorbed anti-laccase immunoglobulins were eluted with $0.5 \%$ propionic acid. Eluted fractions were rapidly neutralized by addition of Tris base and immediately dialysed against PBS. 
C-terminal labelling. Transpeptidation was attempted using the method of Carles et al. (1987), but labelling with $\left[{ }^{35}\right.$ S]methionine rather than tritiated phenylalanine amide. The reaction mixture contained (in $95 \mu \mathrm{l}$ ): $100 \mu \mathrm{mol} \mathrm{KCl}, 0 \cdot 1 \mu \mathrm{mol}$ EDTA, $50 \mu \mathrm{mol} \mathrm{HEPES} / \mathrm{NaOH}$, $\mathrm{pH} 7 \cdot 8,25 \mathrm{nmol} \mathrm{L}-$ methionine, including $30 \mu \mathrm{Ci}(1 \cdot 1 \mathrm{MBq}) \mathrm{L}-\left[{ }^{35} \mathrm{~S}\right]-$ methionine (Amersham), $30 \mu \mathrm{g}$ (approx. $0.5 \mathrm{nmol}$ ) pure laccase and $0.3 \mu \mathrm{g}$ (approx. $5 \mathrm{pmol}$ ) carboxypeptidase Y (Sigma). The mixture therefore contained methionine, laccase and carboxypeptidase $\mathrm{Y}$ in the molar ratios 5000:100:1, assuming a molecular mass of $60 \mathrm{kDa}$ for laccase. The mixture was incubated at $37^{\circ} \mathrm{C}$ for $1 \mathrm{~h}$, after which $45 \mu \mathrm{l}$ was removed and protein recovered by methanol/chloroform precipitation (Wessel \& Flugge, 1984). After 2 h incubation a second $45 \mu \mathrm{l}$ amount was similarly precipitated. Protein precipitates were dissolved in electrophoresis loading buffer, heated for $5 \mathrm{~min}$ on a boiling water bath and separated by SDS-PAGE. Staining and autoradiography of gels are described above.

Western blots. Proteins were transferred electrophoretically from gels to nitrocellulose membranes. Treatment of the membranes with primary antibodies, secondary antibody-enzyme conjugate (peroxidase-goat anti-rabbit IgG (Bio-Rad), washing steps and visualization were performed as described by Zamanian \& Mason (1987).

Indirect immunoprecipitation. The method of Anderson \& Blobel (1983) was used. The reactions were carried out in a total volume of 250 $\mu \mathrm{l}$ PBS containing $5 \mu \mathrm{g}$ affinity-purified anti-SDS-treated laccase antibodies and $40 \mu \mathrm{l}$ sample extract. The mixture was incubated overnight at $4{ }^{\circ} \mathrm{C}$ with continuous mixing. Protein A-agarose $(30 \mu \mathrm{l}$ packed volume; Sigma) was added and after $3 \mathrm{~h}$ incubation with shaking at $37^{\circ} \mathrm{C}$, the agarose beads were recovered by centrifugation, washed four times and finally resuspended in $50 \mu \mathrm{l}$ gel loading buffer. The wash solution was $0 \cdot 1 \%$ Triton X-100, $0.02 \%$ SDS, $150 \mathrm{~mm}-\mathrm{NaCl}$, $5 \mathrm{~mm}$-EDTA, $50 \mathrm{~mm}$-Tris/HCl, $\mathrm{pH} 7 \cdot 4$, except that for the final wash, the detergents were omitted. Labelled antigen protein was released for electrophoretic analysis by boiling for $5 \mathrm{~min}$.

\section{Results and Discussion}

\section{Polypeptide composition of laccase}

SDS-PAGE and Western blot analysis were used to examine crude extracts and pure laccase from both compost culture and malt-extract liquid culture. Coomassie-blue-stained polypeptides, after SDS-PAGE separation, are shown in Fig. 1(a). Purified laccase from both malt-extract and compost cultures showed a predominant band of about $65 \mathrm{kDa}$ apparent molecular mass, together with lesser amounts of smaller polypeptides (the pure enzyme from compost extract is also shown at a higher loading in Fig. 4). The predominant band in crude compost culture extract migrated more slowly and two or three (also more slowly migrating) bands were found for malt-extract culture fluid. Fig. 1(b) shows the same samples analysed as an immunoblot with the primary antibody raised against pure native laccase (from compost). The blot of compost culture fluid and pure laccase from this source showed an essentially identical set of immunoreactive bands, except that the predominant band had migrated more slowly in the unpurified extract. For the material from malt-extract culture the picture is more complex; in the pure enzyme track $\left(\mathrm{M}_{\mathrm{p}}\right)$, although a clear band was present with the same mobility as the predominant band in pure enzyme from compost culture (about $65 \mathrm{kDa}$ ), most of the immunoreactive material was of smaller apparent molecular mass. In addition, the unfractionated culture fluid $\left(\mathrm{M}_{\mathrm{c}}\right)$ showed a distinctly different pattern, with two strongly immunoreactive bands of similar mobility to the two predominant bands revealed in this sample by Coomassie blue staining.

Despite the complexity of the banding patterns shown in Fig. 1(b), only three factors need to be invoked to explain them. First, laccase is composed of a polypeptide, which in a significant proportion of molecules, is proteolytically cleaved so that upon denaturation for SDS-PAGE analysis, numerous polypeptide fragments are revealed as well as full-length (active) main polypeptide. This conclusion was made from the analysis shown in Fig. $1(c)$, where all the immunoreactive bands of compost laccase (versus anti-native laccase) were also detected when the probe was antibody raised against purified main polypeptide. Fig. $1(d)$, in which the probe was antibody to the chemically synthesised 15-mer peptide sequence of the $\mathrm{N}$-terminus of the main polypeptide, shows that a large proportion of the fragment bands of compost laccase contain the $\mathrm{N}$ terminal sequence of the main polypeptide. It further eliminates the possibility that bands other than the main polypeptide detected in Fig. 1(c) were merely from contaminating unrelated protein in laccase preparations used for immunization.

Secondly, the different behaviour of laccase protein from malt-extract culture was less evident when samples were probed with anti-laccase main polypeptide antibody or the anti-N-terminal peptide antibody. The samples from malt-extract culture simply show fewer cleavage products, with the dominant immunoreactive band showing the same mobility as the equivalent band from compost culture samples. The difference between laccase derived from compost and from malt-extract medium can therefore most simply be explained as a result of differences in proteolytic modification and in extent of glycosylation. The latter would explain the greater difference in response to anti-native laccase antibodies (Fig. $1 b$ ), as this antibody preparation would be expected to include a larger fraction of antibodies recognizing surface epitopes of the (non-denatured) enzyme. It is of note that other related proteins also show the characteristic of retaining associated lower molecular mass polypeptides. These have been observed with Aspergillus nidulans laccase (Kurtz \& Champe, 1982) and the blue copper protein from mammalian serum, ceruloplasmin (Takahashi et al., 1984). Fungal cellulases are another group of extracellular enzymes where multiple forms 
(a)

(b)

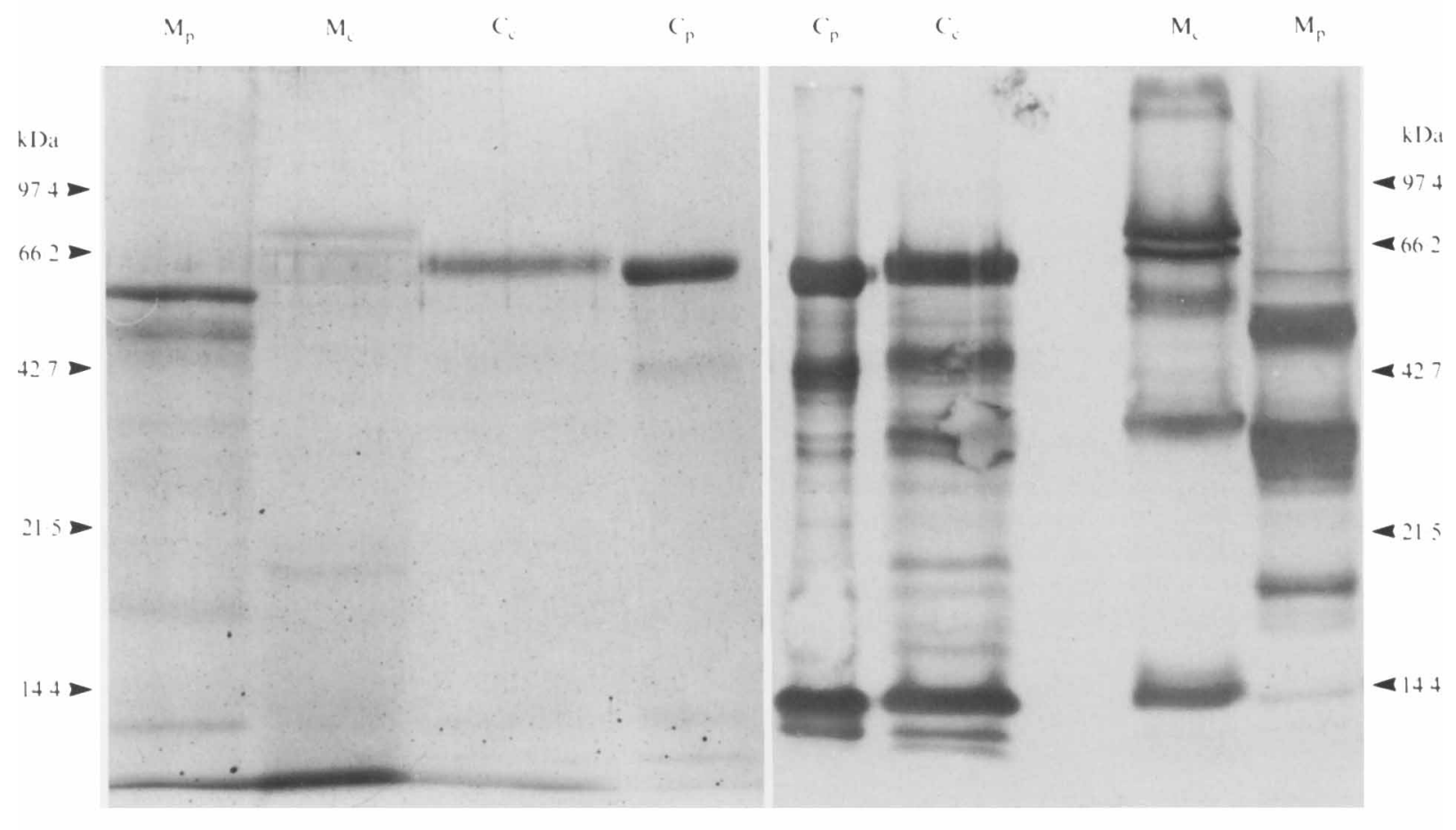

(c)

(d)

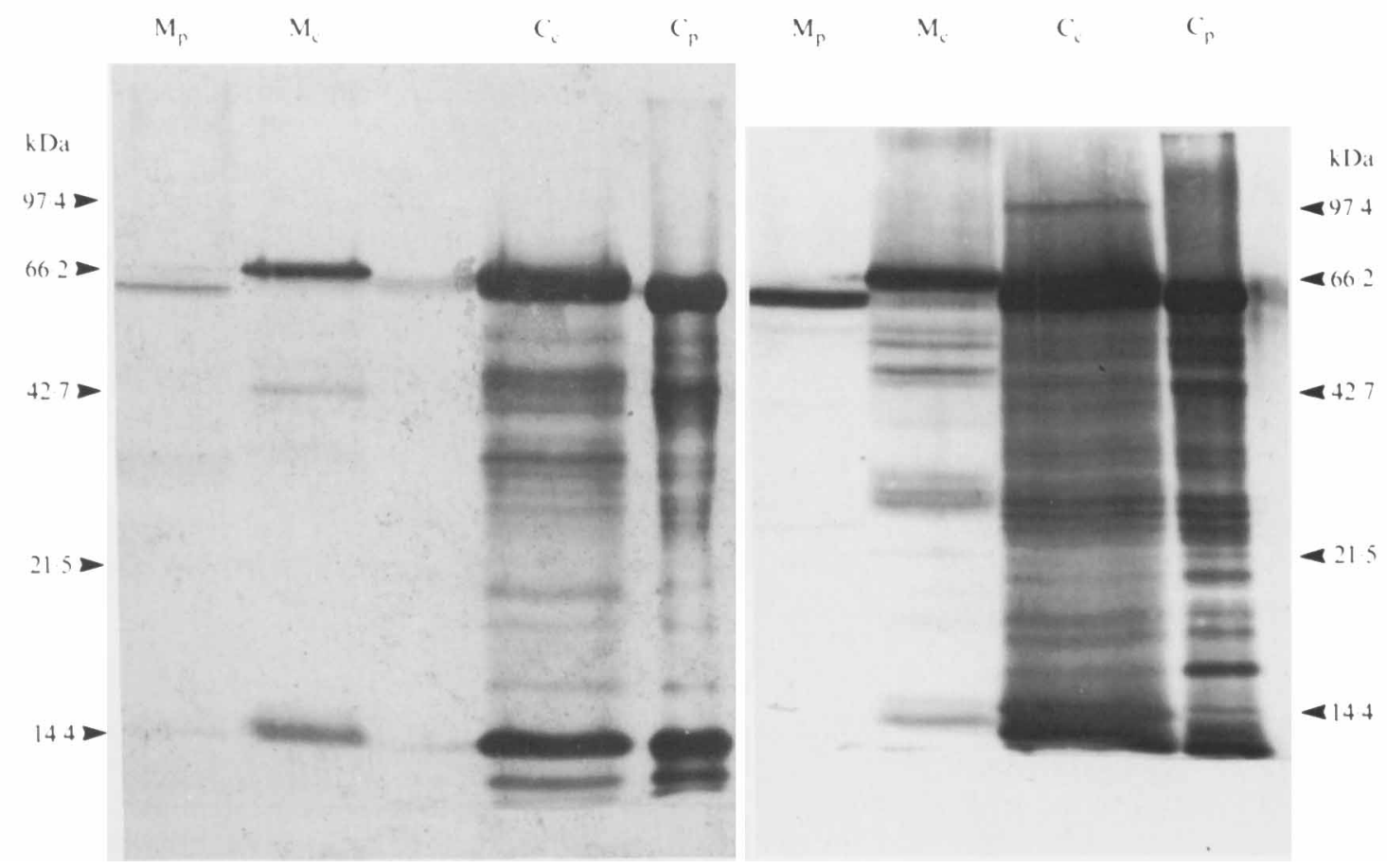

Fig. 1. Western blot analysis of laccase in culture fluid and after purification. (a) Coomassie-blue-stained gel; $(b, c, d)$ Western blots (see Methods). The primary antibodies used were: $(b)$ antiserum raised against native pure laccase from compost culture; $(c)$ antiserum raised against pure laccase main polypeptide, injected in the presence of SDS; $(d)$ antiserum raised against a chemically synthesized peptide with the same sequence as the $15 \mathrm{~N}$-terminal residues of pure laccase from compost culture. Tracks were loaded as follows: $\mathrm{M}_{\mathrm{p}}$, pure laccase from malt extract culture fluid; $\mathrm{M}_{\mathrm{c}}$, malt extract culture fluid; $\mathrm{C}_{\mathrm{p}}$, pure laccase from compost culture; $\mathrm{C}_{\mathrm{e}}$, compost culture fluid. 
(a)

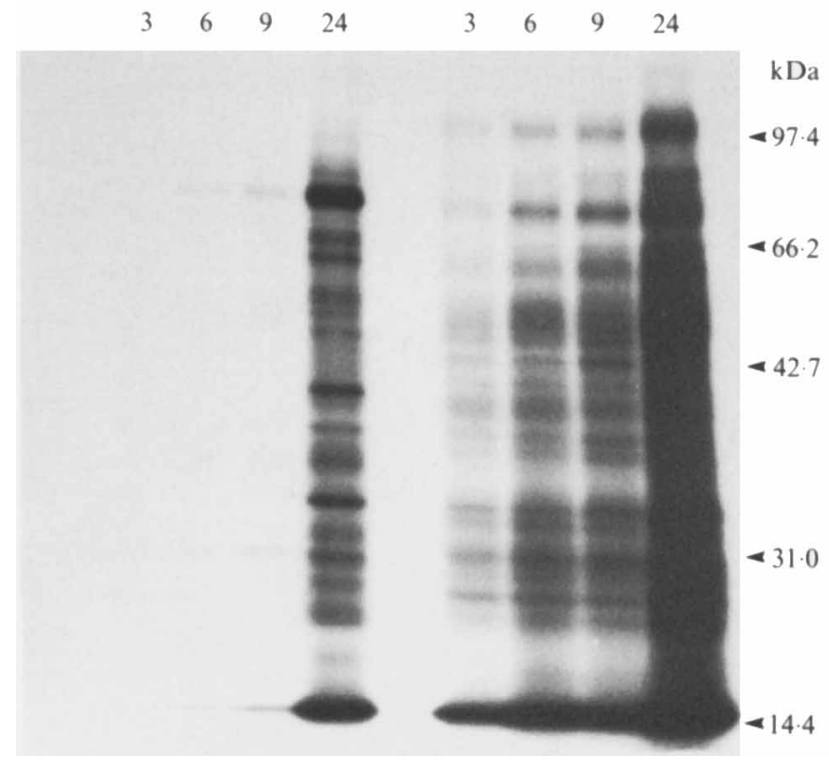

(c)

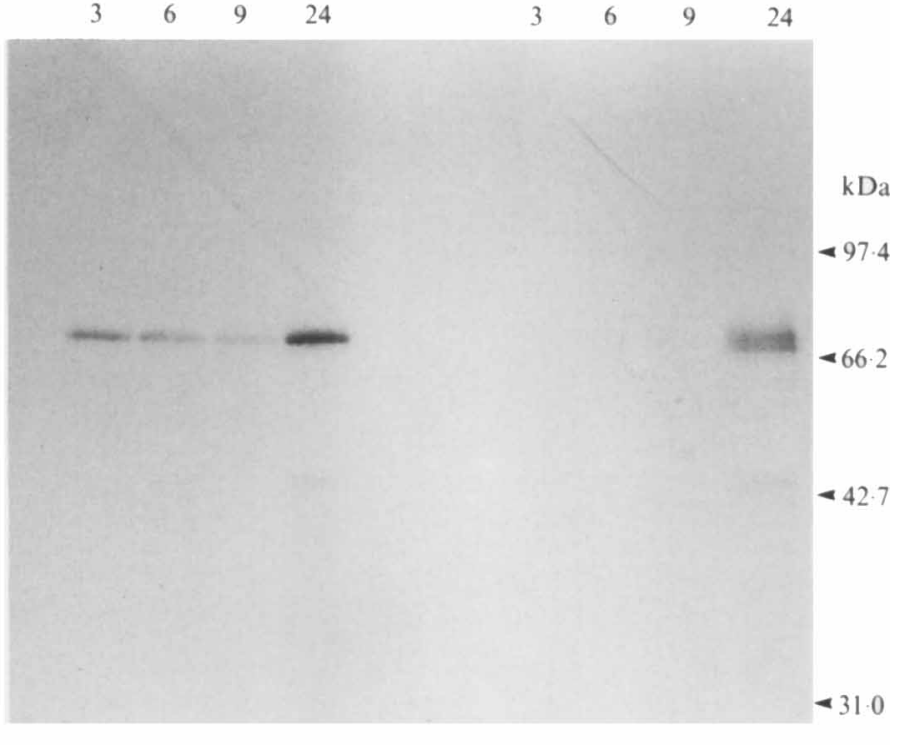

Fig. 2. $\left.{ }^{35} \mathrm{~S}\right]$ Methionine incorporation into laccase by malt-extract-grown $A$. bisporus. Cultures were sampled at 3,6,9 and $24 \mathrm{~h}$ after addition of $\left.{ }^{35} \mathrm{~S}\right]$ methionine to the medium. Autoradiographs show SDS-gel analysis of culture fluid $(a, c)$ and mycelial cell-free extracts $(b, d)$. Total incorporation is shown in $(a)$ and $(b)$ and laccase protein obtained by indirect immunoprecipitation in $(c)$ and $(d)$. The positions of ${ }^{14} \mathrm{C}$-labelled marker proteins and their molecular masses are indicated on the right.

arise by proteolytic modification in culture media (Wood \& Garcia-Campoyo, 1990).

The third factor affecting the data of Fig. 1 is the consistent observation that laccase main polypeptide exhibited a slower electrophoretic mobility as a component of crude culture fluid (both from malt-extract medium and from compost culture) than when purified, that is, the polypeptide appeared to be (some $2-3 \mathrm{kDa}$ ) smaller after purification. This could have resulted from specific cleavage of the molecule during purification, either proteolytic cleavage of an $\mathrm{N}$ - or C-terminal fragment, or some cleavage of carbohydrate residues (since the enzyme is glycosylated). An alternative explanation is that some material was tightly bound to the enzyme such that it was retained during the denaturation step prior to electrophoresis, but nevertheless was separated from the enzyme protein during purification. The latter explanation is considered to be the more likely at present, because it is consistent with the data from in vivo labelling described below and also with the behaviour of a manganese-dependent peroxidase from Phanerochaete chrysosporium described by Andrawis et al. (1990).

\section{Immunoprecipitation of in vivo-labelled laccase polypeptide}

Incorporation of $\left[{ }^{35} S\right]$ methionine into total protein and into immunoprecipitable laccase polypeptide was analysed by autoradiography of electrophoretically separated proteins from both mycelium and culture fluid of a malt-extract culture. Incorporation into mycelial protein (Fig. $2 b$ ) was detectable after $3 \mathrm{~h}$ of labelling and increased with time to $24 \mathrm{~h}$. Labelled protein was not detected in the medium in any great quantity until $24 \mathrm{~h}$ of labelling; however, the most intensely labelled band was also visible in the samples labelled for 6 and $9 \mathrm{~h}$ (Fig. $2 a$ ). Indirect immunoprecipitation with anti-laccase antibody precipitated a single labelled polypeptide. This band was visible at all sampling times from the medium (Fig. $2 c$ ), but only clearly visible in the $24 \mathrm{~h}$ sample from mycelial extract (Fig. 2d). Newly synthesized laccase therefore appeared in the medium as a single polypeptide of a size that could not be distinguished from the main polypeptide of purified enzyme. The intramycelial form of the polypeptide was a double band; the more rapidly migrating species was the same size as the form found in the medium and the other was apparently $1-2 \mathrm{kDa}$ larger (Fig. 2d). Processing of the primary translation product certainly includes glycosylation and may also involve cleavage of terminal peptides. The processing of laccase in Neurospora crassa, for instance, involves cleavage of both $\mathrm{N}$ - and C-terminal fragments (Germann et al., 1988). It is shown below that the laccase primary translation product is significantly smaller than the processed enzyme (in terms of electrophoretic mobility) 


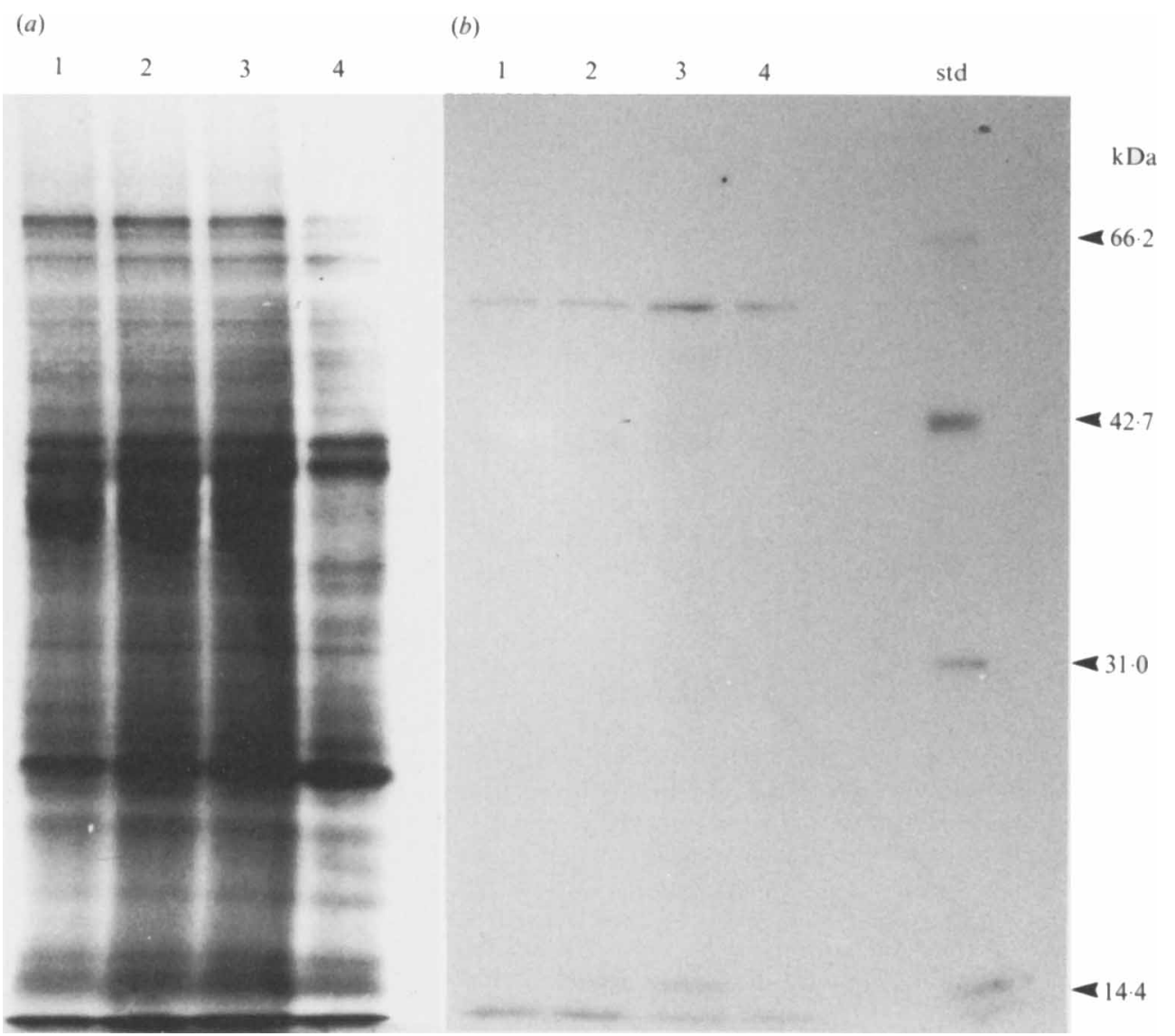

Fig. 3. Immunoprecipitation of laccase polypeptide translated in vitro. Poly(A)-containing RNA was purified from mycelium of 11 -dold malt-extract culture. Rabbit reticulocyte lysate assays $(50 \mu \mathrm{l})$ with $\left[{ }^{35}\right.$ S $]$ methionine as labelled amino acid were given $0 \cdot 25,0 \cdot 5,1 \cdot 0$ and $2.0 \mu \mathrm{g}$ of $A$. bisporus poly(A)-containing RNA (tracks 1-4, respectively). The autoradiograph of an SDS-gel shows total translation products in $(a)$. Laccase polypeptide, isolated from these mixtures by indirect immunoprecipitation (see Methods) is shown in $(b) .{ }^{14} \mathrm{C}$ labelled marker proteins were run in the track marked 'std'.

and it therefore appears that glycosylation is rapid, so that unglycosylated polypeptide was present in too small a quantity to be detected, but a processing step leading to reduction in size was relatively slow so that two forms were detectable. Presence of detectable labelled laccase in the medium before it could be detected in mycelial extract resulted from slow equilibration of the labelled methionine into the intracellular methionine pool, so that the relatively small amount of intracellular enzyme was only detected when the specific activity of methionine in the pool had become relatively high. As laccase is the most abundant protein excreted into the medium (see Fig. $1 a$ ), and given that labelled laccase was precipitated from medium samples that showed only one labelled band (Fig. $2 a$ ), this band can be identified as laccase polypeptide despite its markedly larger apparent molecular mass (about $70 \mathrm{kDa}$ ) than the equivalent immunoprecipitated band $(65-67 \mathrm{kDa})$. As argued above, laccase subjected to electrophoresis in crude medium samples showed retarded mobility due to binding of some other component(s) in the medium.

\section{Immunoprecipitation of laccase polypeptide from products of in vitro translation}

Affinity-purified anti-laccase main polypeptide IgG was used to purifiy laccase mRNA translation products from rabbit reticulocyte lysate assays that had been given 0.25-2 $\mu \mathrm{g}$ amounts of poly(A)-containing RNA, isolated from mycelium of 11-d-old $A$. bisporus cultures. For all amounts of mRNA assayed, the predominant labelled polypeptide adsorbed by the antibody was of about $57 \mathrm{kDa}$ molecular mass by comparison with protein standards on SDS-PAGE analysis (Fig. $3 b$ ). Extended exposure of autoradiographs of the gels revealed the presence of minor labelled bands of lower apparent molecular mass. As the most intense of these bands could be superimposed on heavily labelled bands in the total 


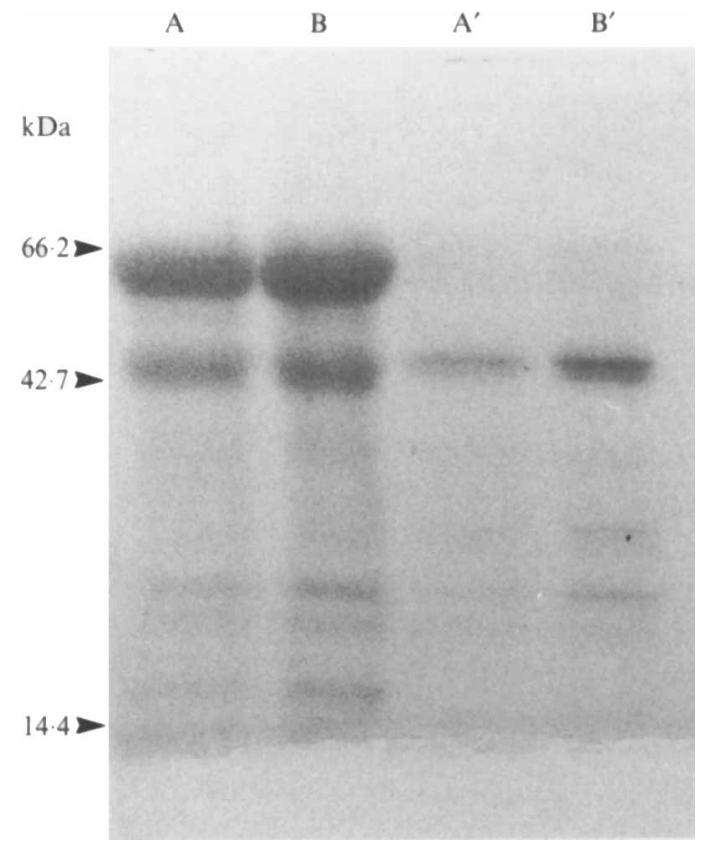

Fig. 4. Attempted C-terminal labelling of pure A. bisporus laccase. Laccase purified from compost extract was labelled by transpeptidation with carboxypeptidase $\mathrm{Y}$ in the presence of $\left[{ }^{35} \mathrm{~S}\right]$ methionine. Tracks $\mathrm{A}$ and $B$ show samples stained with Coomassie blue after $60 \mathrm{~min}$ and 120 min of labelling, respectively, and electrophoresis on a $10 \%$ SDS-gel. In order to reveal incorporation of labelled methionine, an autoradiograph of the gel has been photographed on top of it, displaced laterally so that tracks $A^{\prime}$ and $B^{\prime}$ show the radioactivity in tracks $A$ and $B$, respectively. Both tracks were loaded with approximately $14 \mu \mathrm{g}$ laccase protein.

translation products (Fig. $3 a$ ), it could not be determined whether these were antigenic polypeptides or merely the result of a low level of non-specific carryover. It is clear from Fig. 3 that, although laccase is an abundantly produced protein in vivo, it is not an abundant product of translation of poly(A)-containing RNA in the rabbit reticulocyte lysate system. The molecular mass $(57 \mathrm{kDa})$ of the laccase primary translation product corresponds to that derived from the gene sequences of other fungal laccases. Saloheimo et al. (1991) have shown that the molecular mass calculated from the ORF of the laccase gene from Phlebia radiata is $54.44 \mathrm{kDa}$ and similar values were already established for Neurospora crassa (German et al., 1988), Coriolus hirsutus (Kojima et al., 1990) and Aspergillus nidulans (Aramoyo \& Timberlake, 1990). The closely related blue copper oxidases (ascorbate oxidase) from plants also show a similar size of gene product (Esaka et al., 1990).

\section{Attempted C-terminal labelling of laccase}

Given that the processing of laccase from primary translation product to active extracellular enzyme is complex, it would be desirable to determine as many structural features of the processed enzyme as is practicable. Fig. 4 shows the result of C-terminal labelling by carboxypeptidase-catalysed transpeptidation of pure native laccase. Several of the more abundant fragment polypeptides were successfully labelled, but the main polypeptide was not labelled. The C-terminus of the uncleaved polypeptide is therefore either blocked or folded into the enzyme molecule so that it is protected from attack by carboxypeptidase. These data support the conclusion that many of the smaller polypeptides have the C-terminal end of the full-length polypeptide cleaved off.

\section{Laccase glycosylation}

Previous study of laccase purified from malt-extract culture showed that the carbohydrate content of the enzyme was approximately $15 \%$ (Wood, $1980 a$ ). Treatment of pure (compost) enzyme with $N$-glycanase increased the mobility on SDS-PAGE of the main polypeptide equivalent to a reduction in molecular mass of about $5 \mathrm{kDa}$ (not shown). The change in electrophoretic mobility suggests that the enzyme contained about equal amounts of $\mathrm{N}$ - and $O$-linked carbohydrate. More precise estimation of carbohydrate content and the size of glycosylated forms of the protein cannot be derived from electrophoretic mobilities because the contribution of the carbohydrate to electrophoretic mobility is unpredictable. The in vivo labelling study (Fig. 2) shows that laccase glycosylation occurs rapidly prior to secretion. All fungal laccases analysed so far have been shown to be glycosylated, often to a surprisingly large extent (Reinhammar, 1984). The structure and role of the glycans of fungal laccases remain to be determined. The structure of a plant laccase has been determined and shown to comprise a set of biantennary complex types of glycan that share a common xylose-rich core unit (Takahashi et al., 1986).

\section{Conformation of native laccase}

As discussed above, $A$. bisporus laccase is composed of a glycosylated polypeptide of about $65 \mathrm{kDa}$, which in a proportion of molecules is proteolytically 'nicked', as has been found for other fungal laccases. There remains, however, an uncertainty over the conformation of the native enzyme molecule. Native fungal laccases show a large size diversity, ranging from 64 to $320 \mathrm{kDa}$ (Reinhammar, 1984; Wood, 1980a). A. bisporus laccase has a native molecular mass of $100 \mathrm{kDa}$, determined both by sedimentation analysis and by gel filtration (Wood, 1980a). As both these methods are difficult to calibrate for glycoproteins, the value may not be exact. 
but it does not fit easily with a single polypeptide of about $65 \mathrm{kDa}$. It is at least as likely that the native enzyme is a dimer of identical polypeptides, and this would afford a simpler explanation for the retention of partially cleaved molecules through the purification process.

We gratefully acknowledge the support of the Agricultural and Food Research Council, UK

\section{References}

Ander, P. \& Eriksson, K.-E. (1976). The importance of phenol oxidase activity in lignin degradation by the white rot fungus Sporotrichum pulverulentum. Archives of Microbiology 109, 1-8.

ANDERSON, D. J. \& BLOBEL, G. (1983). Immunoprecipitation of proteins from cell-free translations. Methods in Enzymology 96, $111-120$.

Andrawis, A., Pease, E. A. \& Tien, M. (1990). Extracellular peroxidases of Phanerochaete chrysosporium: cDNA cloning and expression. In Biotechnology in Pulp and Paper Manufacture. Applications and Fundamental Investigations, pp. 601-613. Edited by T. K. Kirk \& H.-M. Chang. Boston: Butterworth-Heinemann.

Aramayo, R. \& Timberlake, W. E. (1990). Sequence and molecular structure of the Aspergillus nidulans $y A$ (laccase 1) gene. Nucleic Acids Research 18, 3415.

BRADFORD, M. M. (1976). A rapid and sensitive method for the quantitation of microgram quantities of protein utilising the principle of protein-dye binding. Analytical Biochemistry 72, 248-254.

Carles, C., Gueguen, P. \& Ribadeau-Dumas, B. (1987). C-terminal labelling of $\beta$-casein. FEBS Letters 212, 163-167.

Esaka, M., Hattori, T., Fujisawa, K., Sakajo, S. \& Asahi, T. (1990). Molecular cloning and nucleotide sequence of full length cDNA for ascorbate oxidase from cultured pumpkin cells. European Journal of Biochemistry 191, 537-541.

German, U. A., Muller, G., Hunziker, P. E. \& Lerch, K. (1988). Characterisation of two allelic forms of Neurospora crassa laccase. Amino- and carboxyl-terminal processing of a precursor. Journal of Biological Chemistry 263, 885-896.

Kojima, Y., Tsukuda, Y., Kawai, Y., Tsukamoto, A., Sugiura, J., SAKAIMO, M. \& KitA, Y. (1990). Cloning, sequence analysis, and expression of lignolytic phenoloxidase genes of the white-rot basidiomycete Coriolus hirsutus. Journal of Biological Chemistry 265, 15224-15230.

Kurtz, M. B. \& Champe, S. P. (1982). Purification and charac- terisation of the conidial laccase of Aspergillus nidulans. Joumal of Bacteriology 151, 1338-1345.

LAEMmLI, U. K. (1970). Cleavage of structural proteins during the assembly of the head of bacteriophage T4. Nature, London 227. 680-685.

Leonard, J. C., Dunham, S. M. \& Thurston, C. F. (1981). Isolation of polysomes and poly(A)-containing RNA from Chlorella fisc a var. vacuolata. New Phytologist 87, 39-51.

Matcham, S. E. \& Wood, D. A. (1992). Purification of Agaricus bisporus extracellular laccase from mushroom compost. Biotechnology Letters 14, 297-300.

Randle, P. E. (1974). Composts. Reports of the Glasshouse Crops Research Institute 1973, 82-84.

Reinhammar, B. (1984). Laccase. In Copper Proteins and Copper Enzymes, vol. III, pp. 1-35. Edited by R. Lontie. Boca Raton: CRC Press.

Saloheimo, M., Niku-Paavola, M.-L. \& Knowles, J. K. C. (1991). Isolation and structural analysis of the laccase gene from the lignindegrading fungus Phlebia radiata. Journal of General Microbiology. 137, 1537-1544.

Smith, J. F., Claydon, N., Love, M. E., Allan, M. \& Wood. D. A. (1989). Effect of substrate depth on extracellular endocellulase and laccase production of Agaricus bisporus. Mycological Research 93. 292-296.

Takahashi, N., Ortel, T. L. \& Putnam, F. W. (1984). Single chain structure of human ceruloplasmin: the complete amino acid sequence of the whole molecule. Proceedings of the National Academy of Sciences of the United States of America 81, 390-394.

Takahashi, N., Hotto, T., Isiharo, H., Mori, M., Tejimo, S., Bliguy, R., Akazawa, T., Eudo, S. \& Arata, Y. (1986). Xylose-containing common structural unit in $N$-linked oligosaccharides of laccase from sycamore cells. Biochemistry 25, 388-395.

Wessel, D. \& Flugge, U. I. (1984). A method for quantitative recovery of protein in dilute solution in the presence of detergents and lipids. Analytical Biochemistry 138, 141-143.

WooD, D. A. $(1980 a)$. Production, purification and properties of extracellular laccase of Agaricus bisporus. Journal of General Microbiology 117, 327-338.

WooD, D. A. $(1980 b)$. Inactivation of extracellular laccase during fruiting of Agaricus bisporus. Journal of General Microbiology 117, 339-345.

Wood, D. A. \& Goodenough, P. W. (1977). Fruiting of Agaricus bisporus. Changes in extracellular enzyme activities during growth and fruiting. Archives of Microbiology 114, 161-165.

Wood, T. M. \& Garcia-CAMPoyo, V. (1990). Enzymology of cellulose degradation. Biodegradation 1, 147-161.

Zamanian, M. \& Mason, J. R. (1987). Benzene dioxygenase in Pseudomonas putida: subunit composition and immunocross-reactivity with aromatic dioxygenases. Biochemical Joumal 244. 611-616. 